\title{
Association of micronutrient status with subclinical health complaints in lactovegetarian adults
}

\author{
Shashi Ajit Chiplonkar and Vaishali Vilas Agte \\ Agharkar Research Institute, Pune, India
}

Abstract

Background: Micronutrient malnutrition has many adverse effects on human health, not all of which may be clinically evident.

Objective: To explore linkages between subclinical health complaints and micronutrient status in lactovegetarian Indian adults.

Design: Health was assessed in 502 lactovegetarian adults ( 275 men, 227 women, aged $30.6 \pm 9$ years) using a structured questionnaire for existing complaints with severity of symptoms on a four-point scale and morbidity over the preceding month. Subjects were categorized as having no complaints (NC), or complaints of mild (MI) or moderate (MD) degree, using cluster analysis. Diet was recorded by a semi-quantitative food frequency questionnaire and nutrient intakes were computed using standard databases. Levels of haemoglobin, vitamin $\mathrm{C}$, retinol, ceruloplasmin, riboflavin (EGRAC), folic acid, vitamin $\mathrm{B}_{12}$ and erythrocyte membrane zinc (RBCMZn) in blood were estimated.

Results: Health complaints of a mild and moderate degree were observed in $30.5 \%$ and $24.7 \%$ of the subjects, respectively. Average dietary intakes of $\beta$-carotene, riboflavin, iron and zinc were observed to be only about half of the recommended dietary intakes. There was a decreasing trend in micronutrient intakes from NC to MD. Intakes of iron, zinc, niacin and thiamin of men from the MI group tended to be lower than in the NC group $(p<0.1)$. Men from the MD group had significantly lower intakes of calcium, zinc and riboflavin than those from the NC group $(p<0.05)$. The intakes of these nutrients in women from NC, MI and MD were not significantly different. Multinomial logistic regression of health status revealed that plasma vitamin $\mathrm{C}$ and RBCMZn were negatively associated with MD and RBCMZn with MI.

Conclusions: The study indicates a need to increase micronutrient intakes of vegetarian populations, especially regarding vitamin $\mathrm{C}$ and zinc for maintenance of health.

Keywords: health complaints; micronutrients; vitamin $C$; zinc

Received: 19 Jul. 2007; Revised: 26 Oct. 2007; Accepted: 28 Oct. 2007

\section{Introduction}

$\mathrm{M}$ ore than 2 billion people in the world today are estimated to be deficient in key vitamins and minerals, particularly vitamin A, iodine, iron and zinc (1). These deficiencies are likely to be prevalent in traditionally vegetarian populations such as Indians, since the micronutrient content of cereals (especially after milling), roots and tubers is low, so these foods typically provide only a small proportion of the daily requirements of most vitamins and minerals. Unless augmented with a variety of fruit and vegetables and taking measures to enhance bioavailability, these populations are at increased risk of several micronutrient deficiencies simultaneously. Dietary micronutrient intakes in
Indians have been observed to be much lower than the recommendations $(2,3)$.

Micronutrient malnutrition has many adverse effects on human health, not all of which are clinically evident (4). Current research has shown that apart from deficiency disorders, micronutrients play a crucial role as cofactors in the activity of almost all enzymes. Many antioxidants such as vitamin $\mathrm{C}$ and carotenoids have been reported as having health-protective effects $(5,6)$. Inadequate micronutrient intakes may reduce resistance to infections and adversely affect the immune system (7). Therefore, there is a need to estimate the magnitude of micronutrient deficiencies and assess their consequences on health (8). The present paper 
attempts to explore linkages of common mild health complaints with micronutrient status in lactovegetarian Indian adults.

\section{Materials and methods}

\section{Subjects}

This cross-sectional study was conducted in a traditionally vegetarian population who consumed milk and milk products. Health surveys were undertaken through private hospitals, clinics and health camps in rural and urban communities in and around Pune city, Maharashtra state, India, in the same season. A total of 598 adults participated in the study voluntarily and gave informed written consent. Of these, 96 participants who had a major illness such as hypertension or diabetes mellitus were excluded from the study. Finally, 502 individuals (227 women and 275 men) were examined for their health and nutritional status.

\section{Dietary nutrient intakes}

A semi-quantitative food frequency questionnaire (FFQ) was used for evaluating habitual dietary intake based on 278 food items consumed throughout the year. The questionnaire was administered by trained investigators using standard measures and portion sizes. Details of the FFQ are given elsewhere (3). Average daily nutrient intakes, i.e. energy, protein, fat, riboflavin, folic acid, $\beta$-carotene, vitamin $\mathrm{C}$, copper, zinc and iron, were computed from food consumption data of the FFQ using the nutritive value database of the authors' laboratory for a variety of cooked foods (9) and the nutritive value tables by Gopalan et al. (10) for raw foods.

\section{Clinical assessment}

With the help of a medical doctor a questionnaire was designed based on different health questionnaires for population survey. These involved selfreported complaints related to general health as well as complaints specifically related to, for example, bone, skin and the respiratory tract (11-13). This questionnaire was pretested on a pilot sample. Another questionnaire was pretested and used to record clinical signs of nutritional deficiencies (14). Clinical examination was carried out by a medical doctor for blood pressure, reflexes of limbs, eyes, chest and abdomen and existing complaints, if any, as reported when filling in the above-mentioned two questionnaires. Morbidity during the preceding 1 month was assessed as occurrence and duration of complaints related to upper respiratory tract infections (URT), eye, gastrointestinal system (GI), skin, bones and joints, central nervous system (CNS) and reproductive system. Complaints such as cough and cold, acidity, anorexia, eye strain, red eyes, photophobia, Bitot's spots, dryness of skin, skin pallor, skin pigmentation, delayed wound healing, muscle pain, bone and joint pain, irritability and nervousness were recorded with grading of severity on a four-point scale: absence of symptom $=0$, mild $=1$, moderate $=2$ and severe $=3$.

\section{Biochemical measurements}

Fasting venous blood $(10 \mathrm{ml})$ was collected in the morning for each subject (not more than $12 \mathrm{~h}$ fasting). Laboratory estimations of plasma retinol, ascorbic acid, folic acid, erythrocyte glutathione reductase activity coefficient (EGRAC) and serum ceruloplasmin were carried out using the methods described in the National Institute of Nutrition manual (15), and erythrocyte membrane zinc (RBCMZn) was estimated as described by Ruz et al. (16).

Criteria used for identifying low micronutrient status were as follows: EGRAC $>1.2$, folic acid $<3.0 \mu \mathrm{g} \mathrm{l}^{-1}$, retinol $\leq 200 \mu \mathrm{g} \mathrm{l}^{-1}$, ascorbic acid $\leq 0.2 \mathrm{mg} \mathrm{l}^{-1}$, vitamin $\mathrm{B}_{12}<160 \mathrm{ng} \mathrm{l}^{-1}$ (17); serum ceruloplasmin $<20 \mathrm{mg} \mathrm{dl}{ }^{-1}$, serum iron $<600 \mu \mathrm{g}^{-1}$ (18); haemoglobin $<14 \mathrm{~g} \mathrm{dl}^{-1}$ for men and $<12 \mathrm{~g} \mathrm{dl}^{-1}$ for women (19).

\section{Statistical methods}

All statistical analyses were performed using SPSS for Windows, version 11.0. A $K$-means cluster analysis was used to identify relatively homogeneous groups of subjects defined from their degree of health complaints (20). The technique aims to group subjects in such a way that the distance between subjects within a group is minimized and the distance between the group centres is maximized. It does this using Euclidean distance measures in $K$-dimensional space, where $K$ is the number of different variables considered. In other words, it aims to put similar subjects in the same group. The three-cluster solution had the best fit to the data. These three clusters were termed no complaints (NC), mild health complaints (MI) and moderate health complaints (MD), representing three levels of the variable health status. Characteristics of the subjects were analysed for 
main effects of health risk and gender with interaction terms using a two-way anova (health status at three levels by gender at two levels). Gender differences were tested using anova. Differences between nutrient intakes in normal (no complaints) versus health complaint groups were tested using the generalized linear models (GLM) univariate procedure with gender and health status as factors. Health status was defined as a three-category variable (NC, MI and MD) with age- and gendermatched individuals in all three groups. To investigate associations of health complaints with biochemical indices of micronutrient status and to judge the risk of suboptimal health, multinomial logistic regression was performed after adjusting for age and weight. Health status of subjects was taken as the dependent variable, taking a value of 0 for MD, 1 for MI and 2 for NC, and the blood levels of micronutrients and lipids were taken as the set of predictor variables.

\section{Results}

General characteristics of the subjects in the three groups are given in Table 1. Differences between body mass index (BMI) or waist to hip circumference ratio (WHR) in different health groups were not statistically significant. Blood pressure was within the normal range in all subjects. There were no significant differences in blood pressure between

Table I. Characteristics of the subjects

\begin{tabular}{lccc}
\hline Parameter & $\begin{array}{c}\text { No complaints } \\
(\mathrm{NC})\end{array}$ & $\begin{array}{c}\text { Mild complaints } \\
(\mathrm{Ml})\end{array}$ & $\begin{array}{c}\text { Moderate } \\
\text { complaints (MD) }\end{array}$ \\
\hline Men $(n=275)$ & & & \\
$n$ & 127 & 93 & 55 \\
Age & $29.7 \pm 1.1$ & $29.7 \pm 1.0$ & $30.6 \pm 1.3$ \\
BMI & $20.5 \pm 0.5$ & $19.8 \pm 0.5$ & $21.6 \pm 0.6$ \\
WHR & $0.88 \pm 0.02$ & $0.88 \pm 0.04$ & $0.87 \pm 0.02$ \\
SBP & $121 \pm 2$ & $115 \pm 2$ & $123 \pm 2$ \\
DBP & $80 \pm 2$ & $77 \pm 1$ & $80 \pm 2$ \\
Women $(n=227)$ & & & \\
$n$ & 97 & 61 & 69 \\
Age & $31.6 \pm 1.6$ & $32.8 \pm 1.2$ & $31.1 \pm 1.2$ \\
BMI & $20.7 \pm 0.8$ & $21.1 \pm 0.8$ & $22.1 \pm 1.0$ \\
WHR & $0.84 \pm 0.02$ & $0.85 \pm 0.02$ & $0.86 \pm 0.05$ \\
SBP & $114 \pm 2$ & $112 \pm 2$ & $113 \pm 5$ \\
DBP & $74 \pm 2$ & $74 \pm 1$ & $73 \pm 2$ \\
\hline
\end{tabular}

Data are shown as mean $\pm \mathrm{SE}$.

BMI: body mass index; WHR: waist to hip ratio; SBP: systolic blood pressure; different groups and also no significant differences between men and women.

Bone and joint pain were reported by $27.5 \%$, URT trouble by $39.6 \%$, eye complaints by $45.2 \%$, GI complaints by $44.5 \%$, skin complaints by $34.1 \%$ and CNS problems by $38.9 \%$ of the individuals. Gynaecological complaints were reported by $21.2 \%$ of the women.

In men, average daily intake of cereals, legumes, vegetables, fruit, milk and milk products was $478 \pm$ $192 \mathrm{~g}$ (mean \pm SD), $148 \pm 109 \mathrm{~g}, 62 \pm 32 \mathrm{~g}, 50 \pm 26 \mathrm{~g}$ and $101 \pm 42 \mathrm{~g}$, respectively. In women, these intakes were $320 \pm 107 \mathrm{~g}, 122 \pm 69 \mathrm{~g}, 71 \pm 43 \mathrm{~g}, 63 \pm 38 \mathrm{~g}$ and $65 \pm 33 \mathrm{~g}$, respectively. Average daily energy intake by men was $2192 \pm 100 \mathrm{kcal}$ and that by women $1678 \pm 73 \mathrm{kcal}$ (Table 2). These were close to the respective recommended dietary intakes (RDIs) for Indians (21). There were no significant differences in macronutrient intakes or polyunsaturated fatty acids (PUFA) intakes among the NC and MI, MD groups, although men's intakes were higher than those of women $(p<0.05)$.

Mean daily intakes of folic acid, copper, calcium and thiamin met the RDI in all subjects. However, average iron intakes in men $\left(18.7 \pm 1.5 \mathrm{mg} \mathrm{day}^{-1}\right)$ and women $\left(13.5 \pm 1.0 \mathrm{mg} \mathrm{day}^{-1}\right)$ were much lower than the RDI of $28 \mathrm{mg}$ day $^{-1}$ for Indians (21). Similarly, average zinc intakes of men and women $\left(7.4 \pm 0.16\right.$ and $5.2 \pm 0.14 \mathrm{mg} \mathrm{day}^{-1}$, respectively) were also lower than the RDI of $15 \mathrm{mg} \mathrm{day}^{-1}$. Mean intakes of $\beta$-carotene (1425 \pm 52 and $1356 \pm$ $68 \mu \mathrm{g} \mathrm{day}^{-1}$ in men and women, respectively) were lower than the RDI. Although there was a decreasing trend in micronutrient intakes from $\mathrm{NC}$ to $\mathrm{MD}$ (Table 2), differences in NC, MI and MD among women were not statistically significant. Intakes of iron, zinc, niacin and thiamin in men were also similar in the different groups. Intakes of calcium, zinc, riboflavin and vitamin $\mathrm{C}$ in men from the $\mathrm{MD}$ group were significantly lower than in the $\mathrm{NC}$ group $(p<0.05)$.

The erythrocyte sedimentation rate (ESR) was within the normal range for all subjects, indicating the absence of chronic infection or inflammation (Table 3). Glucose levels and total cholesterol were also within the normal range for all subjects. Triglycerides were slightly high, between 150 and $175 \mathrm{mg} \mathrm{dl}^{-1}$ for three women and two men from the MI group, and two women and two men from the MD group. A significant difference was observed in 
Table 2. Average daily nutrient intakes of the subjects

\begin{tabular}{|c|c|c|c|c|c|c|}
\hline Nutrient & $\mathrm{RDI}^{\mathrm{a}}$ & $\mathrm{NC}$ & MI & MD & 5th percentile & 95th percentile \\
\hline \multicolumn{7}{|l|}{ Men } \\
\hline Energy (kcal) & 2425 & $2322 \pm 96$ & $2134 \pm 98$ & $2118 \pm 105$ & 1121 & 3630 \\
\hline Protein $(\mathrm{g})$ & 60 & $53.8 \pm 2.4$ & $49.2 \pm 2.2$ & $48.3 \pm 3.2$ & 23.5 & 88.9 \\
\hline Total fat $(\mathrm{g})$ & 20 & $69.8 \pm 3.4$ & $66.9 \pm 3.7$ & $67.5 \pm 4.2$ & 32.1 & 128.4 \\
\hline PUFA $^{\mathrm{b}}(\mathrm{g})$ & $3 \%$ of energy & $39.1 \pm 2.0$ & $39.5 \pm 2.1$ & $41.5 \pm 5.5$ & 17.9 & 63.7 \\
\hline Carbohydrates (g) & - & $368 \pm 15$ & $371 \pm 12$ & $354 \pm 16$ & 170 & 528 \\
\hline Calcium (mg) & 400 & $56 I \pm 37$ & $583 \pm 42$ & $476^{*} \pm 74$ & 191 & 1035 \\
\hline Iron (mg) & 28 & $20.4 \pm 1.2$ & $17.6 \dagger \pm 0.9$ & $18.1 \pm 2.5$ & 6.3 & 32.8 \\
\hline Copper (mg) & 2 & $2.4 \pm 0.1$ & $2.2 \pm 0.1$ & $2.2 \pm 0.2$ & 1.04 & 3.97 \\
\hline Zinc (mg) & 15 & $8.1 \pm 0.4$ & $7.2 \dagger \pm 0.3$ & $6.2^{*} \pm 0.8$ & 3.2 & 12.4 \\
\hline$\beta$-Carotene $(\mu \mathrm{g})$ & 2400 & $1418 \pm 130$ & $|322 \pm 12|$ & $|263 \pm 20|$ & 340 & 3298 \\
\hline Thiamin $(\mu \mathrm{g})$ & 1200 & $1476 \pm 76$ & $1298 \dagger \pm 63$ & $1346 \pm 180$ & 516 & 2373 \\
\hline Riboflavin $(\mu \mathrm{g})$ & 1400 & $797 \pm 37$ & $744 \pm 38$ & $709^{*} \pm 87$ & 316 & 1275 \\
\hline Niacin (mg) & 16 & $15.8 \pm 0.8$ & $13.6 \dagger \pm 0.7$ & $13.8 \pm 1.7$ & 5.5 & 23.9 \\
\hline Folic acid $(\mu \mathrm{g})$ & 100 & $159 \pm 9$ & $148 \pm 7$ & $147 \pm 17$ & 72.3 & 256.6 \\
\hline Vitamin C (mg) & 40 & $52 \pm 8$ & $4 I \pm 5$ & $34^{*} \pm 6$ & 8.1 & 107.1 \\
\hline \multicolumn{7}{|l|}{ Women } \\
\hline Energy (kcal) & 1875 & $1712 \pm 70$ & $1676 \pm 62$ & $1644 \pm 86$ & 870 & 2598 \\
\hline Protein (g) & 50 & $37.3 \pm 2.1$ & $36.7 \pm 1.8$ & $36.9 \pm 1.5$ & 19.3 & 58.2 \\
\hline Total fat (g) & 20 & $60.1 \pm 3.6$ & $57.8 \pm 3.3$ & $56.2 \pm 3.7$ & 22.1 & 96.6 \\
\hline PUFA (g) & $3 \%$ of energy & $29.4 \pm 1.6$ & $29.2 \pm 2.5$ & $28.1 \pm 2.2$ & 12.9 & 49.0 \\
\hline Carbohydrates (g) & - & $242 \pm 14$ & $236 \pm 13$ & $228 \pm 10$ & 123 & 378 \\
\hline Calcium (mg) & 400 & $486 \pm 32$ & $453 \pm 46$ & $462 \pm 44$ & 192 & 792 \\
\hline Iron & 30 & $14.2 \pm 0.7$ & $13.4 \pm 1.2$ & $12.8 \pm 1.1$ & 6.1 & 23.8 \\
\hline Copper (mg) & 2 & $1.6 \pm 0.07$ & $1.6 \pm 0.12$ & $1.5 \pm 0.11$ & 0.8 & 2.6 \\
\hline Zinc & 15 & $5.4 \pm 0.3$ & $5.2 \pm 0.4$ & $4.2 \pm 0.4$ & 2.6 & 8.3 \\
\hline$\beta$-Carotene $(\mu \mathrm{g})$ & 2400 & $1561 \pm 143$ & $1508 \pm 224$ & $1316 \pm 209$ & 306 & 3369 \\
\hline Thiamin $(\mu \mathrm{g})$ & 900 & $991 \pm 44$ & $960 \pm 86$ & $928 \pm 71$ & 422 & 1656 \\
\hline Riboflavin $(\mu \mathrm{g})$ & 1100 & $606 \pm 30$ & $598 \pm 50$ & $556 \pm 43$ & 283 & 967 \\
\hline Niacin (mg) & 12 & $10.6 \pm 0.5$ & $10.0 \pm 0.8$ & $9.6 \pm 0.7$ & 4.8 & 16.3 \\
\hline Folic acid $(\mu g)$ & 100 & $121 \pm 7$ & $118 \pm 11$ & $107 \pm 9$ & 51.3 & 196 \\
\hline Vitamin C (mg) & 40 & $72 \pm 17$ & $48 \pm 18$ & $46 \pm 10$ & 6.3 & 150.6 \\
\hline
\end{tabular}

Data are shown as mean \pm SE.

${ }^{a}$ Recommended dietary intakes (RDI) for Indians (2I).

PUFA: polyunsaturated fatty acids.

${ }^{*} p<0.05, \dagger p<0.1$.

triglycerides between the MD group and the NC group ( $p=0.015)$.

Haemoglobin was marginally below the normal range in $25 \%$ of the men and $36.4 \%$ of the women. Mean plasma vitamin C and RBCMZn were lower in the MD group than in the NC group $(p<0.05)$ (Table 3). No other micronutrient levels were found to be significantly different between the groups $(p>0.1)$. However, the prevalence of low micronutrient status was higher in both men and women in the MD group than in the corresponding NC group (Fig. 1). Low levels of plasma vitamin C $\left(<0.2 \mathrm{mg} \mathrm{dl}^{-1}\right)$ were seen in $16 \%$ of the NC group, $26 \%$ of the MI group and $35 \%$ of the MD group. Low plasma retinol levels $\left(<20 \mu \mathrm{g} \mathrm{dl}^{-1}\right)$ were found more often in women (14-21\%) than in men $(6-12 \% ; p<0.05)$. The prevalence of low serum ceruloplasmin $\left(<20 \mathrm{mg} \mathrm{dl}^{-1}\right)$ was the same in men and women (16-30\%). Around $29 \%$ of men and $48 \%$ of women had low RBCMZn $\left(<0.45 \mathrm{mg} \mathrm{dl}^{-1}\right)$. Low riboflavin status (EGRAC $>1.2$ ) was observed in $40.5 \%$ of men and $52.1 \%$ of women, with no significant differences between groups. The prevalence of low plasma levels of vitamin $\mathrm{B}_{12}$ $\left(<160 \mathrm{ng}^{-1}\right)$ and folic acid $\left(<3 \mu \mathrm{g}^{-1}\right)$ was in the order of $2-4.5 \%$ in all groups, and in both men and women.

To study associations between low micronutrient status and health complaints, correlations of individual complaints with micronutrient levels 
Table 3. Blood levels of haemoglobin, cholesterol, high-density lipoprotein (HDL), glucose, triglycerides and blood micronutrients, and erythrocyte sedimentation rate (ESR), in men and women

\begin{tabular}{|c|c|c|c|c|c|c|}
\hline Parameter & Normal range (17-19) & NC & MI & MD & 5th percentile & 95th percentile \\
\hline \multicolumn{7}{|l|}{ Men } \\
\hline Haemoglobin $\left(\mathrm{g} \mathrm{dl}^{-1}\right)$ & $14-16$ & $14.8 \pm 0.2$ & $14.7 \pm 0.2$ & $14.8 \pm 0.2$ & 12.8 & 17 \\
\hline $\operatorname{ESR}\left(\mathrm{mm} \mathrm{h}^{-1}\right)$ & $1-13$ & $11 \pm 1$ & $13 \pm 1$ & $10 \pm 1$ & 3.3 & 25.0 \\
\hline Total cholesterol $\left(\mathrm{mg} \mathrm{dl}^{-1}\right)$ & $<200$ & $164 \pm 4$ & $160 \pm 5$ & $170 \pm 5$ & 118 & 214 \\
\hline $\mathrm{HDL}\left(\mathrm{mg} \mathrm{dl^{-1 } )}\right.$ & $40-60$ & $45 \pm 1$ & $46 \pm 3$ & $48 \pm 2$ & 26.5 & 61.7 \\
\hline Glucose $\left(\mathrm{mg} \mathrm{dl}^{-1}\right)$ & $70-110$ & $93 \pm 4$ & $95 \pm 4$ & $94 \pm 5$ & 53 & 108 \\
\hline Triglycerides $\left(\mathrm{mg} \mathrm{dl}^{-1}\right)$ & $<150$ & $91 \pm 5$ & $99 \pm 4$ & $97^{*} \pm 4$ & 43 & 143 \\
\hline Plasma vitamin $C\left(\mathrm{mg} \mathrm{l}^{-1}\right)$ & $>0.2$ & $0.31 \pm 0.02$ & $0.26 \pm 0.02$ & $0.25^{*} \pm 0.02$ & 0.12 & 0.44 \\
\hline Plasma retinol $\left(\mu \mathrm{g} \mathrm{dl}^{-1}\right)$ & $>20$ & $25.6 \pm 0.9$ & $25.0 \pm 0.6$ & $25.1 \pm 0.5$ & 19.0 & 31.3 \\
\hline Serum ceruloplasmin $\left(\mathrm{mg} \mathrm{l}^{-1}\right)$ & $>20$ & $20.2 \pm 0.7$ & $21.3 \pm 0.8$ & $19.7 \pm 1.0$ & 12.2 & 30.1 \\
\hline RBCMZn ( $\mu$ mol $g^{-1}$ protein $)$ & $<0.45$ & $0.54 \pm 0.01$ & $0.46 \pm 0.01$ & $0.44^{*} \pm 0.02$ & 0.35 & 0.61 \\
\hline EGRAC & $<1.2$ & $1.12 \pm 0.03$ & $1.13 \pm 0.02$ & $1.1 \pm 0.02$ & 0.83 & 1.6 \\
\hline Plasma folic acid $\left(\mu \mathrm{gl}^{-1}\right)$ & $>3.0$ & $4.6 \pm 0.1$ & $4.3 \pm 0.1$ & $4.5 \pm 0.1$ & 3.1 & 5.9 \\
\hline Serum $B_{12}\left(\left.\mu g\right|^{-1}\right)$ & $>160$ & $434 \pm 12$ & $438 \pm 10$ & $426 \pm 13$ & 285 & 614 \\
\hline \multicolumn{7}{|l|}{ Women } \\
\hline Haemoglobin $\left(\mathrm{g} \mathrm{dl}^{-1}\right)$ & $12-14$ & $12.0 \pm 0.3$ & $12.1 \pm 0.2$ & $12.1 \pm 0.2$ & 8.7 & 14.5 \\
\hline $\operatorname{ESR}\left(\mathrm{mm} \mathrm{h}^{-1}\right)$ & $\mathrm{I}-20$ & $20 \pm 2$ & $24 \pm 2$ & $25 \pm 3$ & 7 & 46 \\
\hline Total cholesterol ( $\left.\mathrm{mg} \mathrm{dl}^{-1}\right)$ & $<200$ & $163 \pm 4$ & $159 \pm 4$ & $|7| \pm 6$ & 113 & 205 \\
\hline $\mathrm{HDL}\left(\mathrm{mg} \mathrm{dl}^{-1}\right)$ & $40-60$ & $50 \pm 2$ & $52 \pm 2$ & $47 \pm 2$ & 30 & 75 \\
\hline Glucose $\left(\mathrm{mg} \mathrm{dl}^{-1}\right)$ & $70-110$ & $78 \pm 2$ & $81 \pm 3$ & $87 \pm 4$ & 54 & 106 \\
\hline Triglycerides $\left(\mathrm{mg} \mathrm{dl}^{-1}\right)$ & $<150$ & $71 \pm 3$ & $8 I \pm 5$ & $89 * \pm 6$ & 45 & 131 \\
\hline Plasma vitamin $C\left(\mathrm{mg} \mathrm{l}^{-1}\right)$ & $>0.2$ & $0.32 \pm 0.02$ & $0.30 \pm 0.02$ & $0.22 * \pm 0.01$ & 0.13 & 0.49 \\
\hline Plasma retinol $(\mu \mathrm{g} \mathrm{dl}-1)$ & $>20$ & $24.5 \pm 0.7$ & $24.2 \pm 0.6$ & $24.0 \pm 1.0$ & 16.7 & 30.7 \\
\hline Serum ceruloplasmin $\left(\mathrm{mg} \mathrm{l}^{-1}\right)$ & $>20$ & $23.1 \pm 1.2$ & $22.5 \pm 1.1$ & $22.9 \pm 0.7$ & 13.4 & 43.3 \\
\hline RBCMZn ( $\mu \mathrm{mol} \mathrm{g}^{-1}$ protein) & $<0.45$ & $0.52 \pm 0.01$ & $0.49 \pm 0.02$ & $0.43^{*} \pm 0.01$ & 0.30 & 0.60 \\
\hline EGRAC & $<1.2$ & $1.2 \pm 0.02$ & $1.22 \pm 0.01$ & $1.24 \pm 0.02$ & 1.0 & 1.6 \\
\hline Plasma folic acid $\left(\mu \mathrm{g} \mathrm{I}^{-\mathrm{I}}\right)$ & $>3.0$ & $4.4 \pm 0.2$ & $4.1 \pm 0.1$ & $3.8 \pm 0.1$ & 3.2 & 5.5 \\
\hline Serum $B_{12}\left(\mu \mathrm{gl}^{-1}\right)$ & $>160$ & $424 \pm 11$ & $413 \pm 11$ & $388 \pm 13$ & 276 & 543 \\
\hline
\end{tabular}

Data are shown as mean $\pm \mathrm{SE}$.

RBCMZn: erythrocyte membrane zinc; EGRAC: erythrocyte glutathione reductase activity coefficient. $*_{p}<0.05$.

were first examined. Plasma vitamin C exhibited a significant negative correlation with almost all individual complaints $(p<0.05)$. RBCMZn, retinol, haemoglobin and riboflavin also showed an association with health complaints (Table 4). For other micronutrient levels, i.e. vitamin $\mathrm{B}_{12}$, folic acid and ceruloplasmin, correlations were very low and not statistically significant.

To estimate the relative influences of these micronutrients on health status, a multinomial logistic regression was performed after accounting for differences in age and weight. The dependent variable health status had three categories: NC, MI and MD. Blood levels of eight micronutrients, triglycerides and cholesterol were the 10 independent variables. Comparison of the $\mathrm{NC}$ group with the MI group showed that RBCMZn had a significant negative association with health status $(p=0.001)$ (Table 5). When the MD group was compared with the $\mathrm{NC}$ group, $\mathrm{RBCMZn}$ and serum vitamin $\mathrm{C}$ were negatively related factors $(p<0.01)$.

\section{Discussion}

In this study population of apparently healthy individuals, subclinical health complaints of mild degree were reported by $30.5 \%$ of the subjects and of moderate degree by $24.7 \%$. Although the assessment of subclinical health complaints may involve subjective bias, care was taken to reduce this bias in self-reporting by using standard techniques and examination by the doctor. Moreover, such health status measures have been reported to provide reliable data (11).

Regarding macronutrients, mean fat intakes were higher than the RDI in both men and women in all three health status groups. Similar high fat intakes, especially higher saturated fat intakes, have been reported previously in Indian adults $(3,22,23)$. 

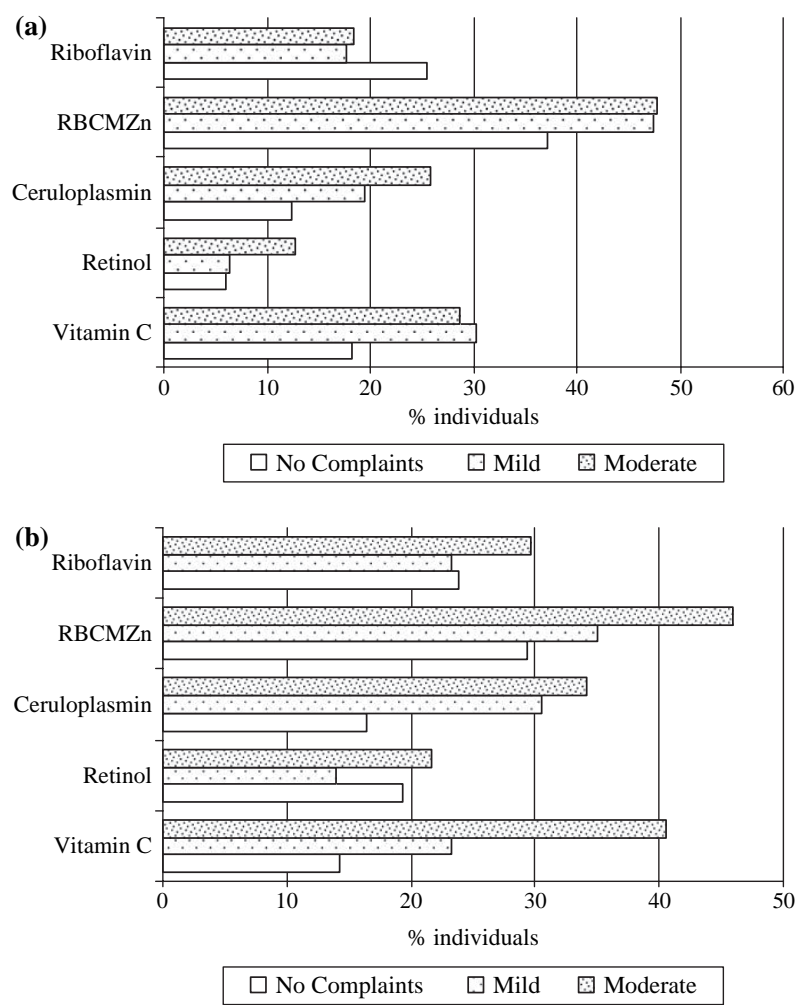

Fig. 1. Percentage prevalence of low blood levels of micronutrients in (a) men and (b) women. RBCMZn: erythrocyte membrane zinc.

The invisible fats present in many Indian foods have a high linoleic acid content (rice $50 \%$, wheat $55 \%$, Bengalgram $65 \%$, redgram $58 \%$ ) and linolenic acid content of about $3 \%$. As a result, the average Indian diet, which is predominantly based on cereals and some legumes, contains sufficient linoleic and linolenic acid (21). Together with cooking oils, this may be the reason for the high PUFA intakes of the study groups. Studies on tissue levels of long-chain $n$-3 fatty acids show that these are depressed in vegetarians, particularly in vegans (24). However, a study of normal healthy Indians indicated blood levels of essential fatty acids to be satisfactory (25). Fatty acid levels in blood were not measured in the present study, but no significant differences were seen in PUFA intakes between the three health status groups.

The results showed that mean daily iron intakes were only about half of the RDI. Furthermore, $74.4 \%$ of adults had zinc intakes less than half the RDI, $52 \%$ had low $\beta$-carotene intakes, $44 \%$ had low riboflavin intakes and $34 \%$ had low vitamin $C$ intakes. Low micronutrient intakes have also been reported by other Indian studies (2) and in Western populations $(26,27)$. The present study group was lactovegetarian, with low consumption of vegetables $\left(66 \pm 45 \mathrm{~g} \mathrm{day}^{-1}\right)$ and fruit $\left(66 \pm 45 \mathrm{~g} \mathrm{day}^{-1}\right)$, and also of milk and milk products $(86 \pm 67 \mathrm{~g}$ day $^{-1}$ ). This may be the reason for their low intakes of vitamins and minerals. Similar low consumption of fruit and vegetables has been found to result in low vitamin $\mathrm{C}$ intakes (27).

Intake of animal foods in the study group was restricted only to milk products. This could be one of the factors behind low micronutrient status, especially regarding iron (28). Iron and zinc deficiencies have been reported in the developing as well as the developed world $(29,30)$. For instance, lifelong vegetarians in Belgium were also found to have deficiencies of calcium, zinc, iron, and vitamins $\mathrm{B}_{6}$ and $\mathrm{B}_{12}$ (30). There is a real risk of vegan populations becoming deficient unless they change their eating habits or take a supplement (31). However, micronutrient status can be enhanced by increasing the intake of vegetables and fruit, and by improving the bioavailability of micronutrients by appropriate methods such as sprouting or fermentation $(32,33)$.

There was a decreasing trend in micronutrient intakes from NC to MD. This was reflected in the corresponding blood levels. Even in the NC group,

Table 4. Correlations between individual health complaints and blood levels of micronutrients

\begin{tabular}{|c|c|c|c|c|c|}
\hline Complaints & Plasma vitamin C & $\mathrm{RBCMZn}$ & Plasma retinol & Haemoglobin & Riboflavin (EGRAC) \\
\hline Bones and joints & $-0.23(p=0.00 \mathrm{I})$ & $-0.10(p=0.09)$ & $0.045(p=0.49)$ & $0.09(p=0.16)$ & $0.07(p=0.33)$ \\
\hline URT & $-0.12(p=0.053)$ & $-0.08(p=0.24)$ & $0.131(p=0.03)$ & $(0.01)(p=0.9)$ & $0.12(p=0.06)$ \\
\hline Eye & $-0.145(p=0.012)$ & $-0.11(p=0.07)$ & $0.08(p=0.17)$ & $-0.07(p=0.24)$ & $0.14(p=0.018)$ \\
\hline $\mathrm{Gl}$ & $-0.16(p=0.006)$ & $-0.12(p=0.049)$ & $0.013(p=0.82)$ & $-0.03(p=0.61)$ & $0.08(p=0.15)$ \\
\hline Skin & $-0.12(p=0.048)$ & $-0.07(p=0.32)$ & $0.10(p=0.13)$ & $-0.11(p=0.08)$ & $0.01(p=0.89)$ \\
\hline CNS & $-0.091(p=0.118)$ & $-0.08(p=0.21)$ & $0.082(p=0.17)$ & - & $0.08(p=0.17)$ \\
\hline Total health complaints & $-0.17(p=0.017)$ & $-0.155(p=0.034)$ & $0.054(p=0.45)$ & $-0.04(p=0.53)$ & $0.15(p=0.03)$ \\
\hline
\end{tabular}

RBCMZn: erythrocyte membrane zinc; EGRAC: erythrocyte glutathione reductase activity coefficient; URT: upper respiratory tract; Gl: gastrointestinal; CNS: central nervous system. 
Table 5. Maximum likelihood fit of the multinomial logistic model

\begin{tabular}{lcc}
\hline & \multicolumn{2}{c}{ Estimate of $\beta$-values } \\
\cline { 2 - 3 } Variable & Moderate (MD) vs & Mild (MI) vs \\
& normal (NC) & normal (NC) \\
\hline Intercept & 0.523 & 1.98 \\
Haemoglobin & 0.012 & -0.032 \\
Plasma vitamin C & $-4.292^{* *}$ & -0.154 \\
Plasma retinol & 0.057 & 0.01 \\
Plasma folic acid & 0.049 & 0.037 \\
Serum ceruloplasmin & -0.022 & 0.002 \\
Serum total cholesterol & 0.01 & -0.001 \\
Triglycerides & 0.005 & 0.007 \\
RBCMZn & $-5.849 * *$ & $-4.072^{* *}$ \\
EGRAC & 0.471 & -0.611 \\
Vitamin B & -0.002 & 0.001 \\
\hline
\end{tabular}

RBCMZn: erythrocyte membrane zinc; EGRAC: erythrocyte glutathione reductase activity coefficient.

$*^{* *} p<0.01$.

$14 \%$ of subjects had low serum levels of various micronutrients, and the prevalence increased to $35 \%$ in the MI group and 47\% in the MD group. Further examination of the data by multinomial logistic regression analysis revealed that low levels of vitamin $\mathrm{C}$ and zinc were risk indicators for subclinical health complaints. The association of low zinc status, as indicated by low RBCMZn, with health complaints suggests a need for improving bioavailable zinc intakes.

These results on young adults agree well with many studies on older age groups reporting an association between micronutrient deficiencies and health disorders. Low serum micronutrient concentrations in disabled older women were found to be an independent risk factor for frailty, and the risk of frailty increased with the number of micronutrient deficiencies (34). Zinc has been found to be one of the significant predictors of immune function in older women (35).

Evidence from epidemiological studies supports the importance of an optimal micronutrient status to help to prevent chronic diseases such as coronary heart disease, cancer, mental degeneration, diabetes and age-related macular degeneration. Antioxidant micronutrients such as vitamin $\mathrm{C}$ or $\beta$-carotene may be particularly important $(5,36,37)$. Increased fruit and vegetable consumption has been associated with a lower prevalence of coronary heart disease and some cancers, although reductions are sometimes modest and not statistically significant (38).
The results demonstrated associations between low zinc and vitamin $\mathrm{C}$ status and common health complaints in young adults, indicating the need for alleviating micronutrient malnutrition. One of the limitations of this study, however, is the relatively small sample size. Further studies are necessary to confirm the results. Another limitation is that the clusters identified in this paper apply specifically to the clinical signs of nutritional deficiencies and general health complaints and should not be extrapolated to the entire spectrum of health disorders. In conclusion, however, this study highlights the importance of increasing the dietary intake of micronutrients, especially vitamin $\mathrm{C}$ and zinc, for the maintenance of good health.

\section{Acknowledgements}

This work was a part of the research project funded by the Department of Science and Technology, New Delhi, India (Project No. SP/SO/B39/94).

\section{References}

1. World Health Organization. The World Health Report : reducing risks, promoting healthy life. Geneva: WHO; 2001. p. 2001.

2. Chakravarty I, Sinha RK. Prevalence of low micronutrient status based on results obtained from the national pilot program on control of micronutrient malnutrition. Nutr Rev 2002; 60: S53-8.

3. Chiplonkar SA, Agte VV, Mengale SS, Tarwadi KV. Are lifestyle factors good predictors of retinol and vitamin $\mathrm{C}$ deficiency in apparently healthy adults? Eur J Clin Nutr 2002; 56: 96-104.

4. Lindsay A, de Benoist B, Dary O, Hurrell R, eds. Guidelines on food fortification with micronutrients. Geneva: World Health Organization and Food and Agriculture Organization of the United Nations; 2006.

5. Wannamethee SG, Lowe GD, Rumley A, Bruckdorfer KR, Whincup PH. Associations of vitamin C status, fruit and vegetable intakes, and markers of inflammation and hemostasis. Am J Clin Nutr 2006; 83: 567-74; quiz 726-7.

6. Heinrich U, Tronnier H, Stahl W, Bejot M, Maurette JM. Antioxidant supplements improve parameters related to skin structure in humans. Skin Pharmacol Physiol 2006; 19: 224-31.

7. Latham MC. Human nutrition in the developing world. Food and Nutrition Series No. 29. Rome: FAO (Food and Agriculture Organization of the United Nations); 1997. ISSN 1014-3181.

8. Bhan MK, Sommerfelt H. Micronutrients, maternal and child health. Br J Nutr 2001; 85(Suppl 2): S65.

9. Chiplonkar SA, Agte VV. Extent of error in estimating nutrient intakes from food tables versus laboratory 
estimates of cooked foods. Asia Pac J Clin Nutr 2007; 16: 227-39.

10. Gopalan C, Ramasastri BV, Balasubramanian SG. Revised and updated by Rao BSN, Deosthale YB, Pant KC. Nutritive value of Indian foods. Hyderabad: National Institute of Nutrition; 1993.

11. Gelijns AC, ed. Modern methods of clinical investigation. Committee on Technological Innovation in Medicine, Institute of Medicine. Washington, DC: National Academy Press; 1990.

12. Dalgard F, Svensson A, Holm JØ, Sundby J. Selfreported skin complaints: validation of a questionnaire for population surveys. Br J Dermatol 2003; 149: 794-800.

13. Pincus T, Sokka T. Quantitative measures for assessing rheumatoid arthritis in clinical trials and clinical care. Best Pract Res Clin Rheumatol 2003; 17: 753-81.

14. Gibson RS. Principles of nutritional assessment, 2nd revised edn. New York: Oxford University Press; 2005.

15. Raghuramulu N, Madhavan Nair K, Kalyansundaram S. A manual of laboratory techniques. Hyderabad: National Institute of Nutrition, Indian Council of Medical Research; 2003.

16. Ruz M, Cavan KR, Bettger WJ, Gibson RS. Erythrocytes, erythrocyte membranes, neutrophils and platelets as biopsy materials for the assessment of zinc status in humans. Br J Nutr 1992; 68: 515-27.

17. Grusse JL, Watier B. Les vitamins. France: Centre D'Etude et d'Information Sur les Vitamines Cedex, Produits Roche; 1993. p. 48.

18. Turnland JR. Copper. In: Shils ME, Olson JA, Shike M, eds. Modern nutrition in health and disease, 8th edn. Philadelphia, PA: Lea \& Febiger; 1994. p. 231-41.

19. Cook JD, Dallman PI, Bothwell TH, Lynch SR, Covell AM, Worwood MA, Reusser ME. A Report of International Nutritional Anemia Consultative Group. Measurement of iron status. Washington, DC: Nutrition Foundation; 1985. p. 75.

20. Everitt BS. Statistical methods for medical investigations, 2nd edn. London: Edward Arnold; 1994.

21. ICMR. Nutrient requirements and recommended dietary allowances for Indians. A report of the expert group of the Indian Council of Medical Research. Hyderabad: Indian Council of Medical Research; 2000.

22. Achaya KT. Fat intakes in India. New Delhi: Nutrition Foundation of India Bulletin, April 1986.

23. Beegom R, Singh RB. Association of higher saturated fat intake with higher risk of hypertension in an urban population of Trivandrum in south India. Int $\mathbf{J}$ Cardiol 1997; 58: 63-70

24. Davis BC, Kris-Etherton PM. Achieving optimal essential fatty acid status in vegetarians: current knowledge and practical implications. Am J Clin Nutr 2003; 640-6S.

25. Ghafoorunissa. Essential fatty acid nutritional status of apparently normal Indians. Human Nutr Clin Nutr 1987;38C:269.

26. Leblanc JC, Yoon H, Kombadjian A, Verge P. Nutritional intakes of vegetarian populations in France. Eur $\mathbf{J}$ Clin Nutr 2000; 54: 443-9.
27. Taylor CA, Hampl JS, Johnston CS. Low intakes of vegetables and fruits, especially citrus fruits, lead to inadequate vitamin $\mathrm{C}$ intakes among adults. Eur J Clin Nutr 2000; 54: 573-8.

28. Institute of Medicine. Dietary reference intakes for vitamin A, vitamin $\mathrm{K}$, arsenic, boron, chromium, copper, iodine, iron, manganese, molybdenum, nickel, silicon, vanadium, and zinc. Washington, DC: National Academy Press; 2000.

29. Ma G, Jin Y, Li Y, Zhai F, Kok FJ, Jacobsen E, Yang X. Iron and zinc deficiencies in China: what is a feasible and cost-effective strategy? Public Health Nutr 26 Sept 2007; 1-7. Epub ahead of print; doi: 10.1017/ S1368980007001085

30. Clarys P, Deriemaeker P, Hebbelinck M, Bosmans D, Bertier B. Physical fitness and health-related parameters in Flemish life-long vegetarians: a pilot study. Nutr Food Sci 2004; 34: 29-41.

31. Biesalski HK, Brummer RJ, König J, O'Connell MA, Ovesen L, Rechkemmer G, et al. Micronutrient deficiencies. Hohenheim Consensus Conference. Eur J Nutr 2003; 42: 353-63.

32. Agte VV, Tarwadi KT, Chiplonkar SA. Phytate degradation during traditional cooking: significance of phytate profile in cereal based vegetarian diets. J. Food Comp Anal 1999; 12: 161-7.

33. Agte VV, Jahagirdar M, Chiplonkar SA. GLV supplements increased plasma beta-carotene, vitamin $C$, zinc and hemoglobin in healthy adults. Eur J Nutr 2006; 45: 29-36.

34. Semba RD, Bartali B, Zhou J, Blaum C, Ko CW, Fried LP. Low serum micronutrient concentrations predict frailty among older women living in the community. J Gerontol A Biol Sci Med Sci 2006; 6: 594-9.

35. Molls RR, Ahluwalia N, Mastro AM, Smiciklas-Wright H, Handte GC. Nutritional status predicts primary subclasses of $\mathrm{T}$ cells and the lymphocyte proliferation response in healthy older women. J Nutr 2005; 135: 2644-50.

36. Ching S, Ingram D, Hahnel R, Beilby J, Rossi E. Serum levels of micronutrients, antioxidants and total antioxidant status predict risk of breast cancer in a case control study. J Nutr 2002; 132: 303-6.

37. John JH, Ziebland S, Yudkin P, Roe LS, Neil HA. Effects of fruit and vegetable consumption on plasma antioxidant concentrations and blood pressure: a randomized controlled trial. Lancet 2002; 359: 1969-74.

38. Hung HC, Joshipura KJ, Jiang R, Hu FB, Hunter D, Smith-Warner SA, et al. Fruit and vegetable intake and risk of major chronic disease. J Natl Cancer Inst 2004; 96: $1577-84$.

\footnotetext{
Shashi Ajit Chiplonkar

Agharkar Research Institute

G G Agarkar Road

Pune 4I I 004, India

Tel: +9| 2025654357

Fax: +91 2025651542

E-mail: shashi49@indiainfo.com, drsjc_l@yahoo.com
} 